\title{
HCV INFECTION AND CHRONIC RENAL DISEASE
}

Sofija Sekulic ${ }^{1}$, Zeljko Mijailovic ${ }^{1}$, Dejan Petrovic ${ }^{2}$, Ruzica Lukic ${ }^{3}$, Marina Jovanovic ${ }^{4,5}$ and Ivan Jovanovic ${ }^{5}$

${ }^{1}$ Department of Infectious diseases, Faculty of Medical Sciences, University of Kragujevac, Serbia

${ }^{2}$ Department of Internal medicine, Faculty of Medical Sciences, University of Kragujevac, Serbia ${ }^{3}$ Department of Microbiology, Faculty of Medicine Foca, University of East Sarajevo, Bosnia and Herzegovina

${ }^{4}$ Department of Otorhinolaryngology, Faculty of Medical Sciences, University of Kragujevac, Serbia

${ }^{5}$ Center for Molecular Medicine and Stem Cell Research, Faculty of Medical Sciences, University of Kragujevac, Serbia

\author{
HCV INFEKCIJA II HRONIČNA BUBREŽNA BOLEST \\ Sofija Sekulić ${ }^{1}, Z_{\text {eljko Mijailović }}$, Dejan Petrović ${ }^{\text {, Ružica Lukić }}{ }^{3}$, Marina Jovanović ${ }^{4,5}$ i Ivan Jovanovićs \\ ${ }^{I}$ Katedra za zarazne bolesti, Fakultet medicinskih nauka, Univerzitet u Kragujevcu, Srbija \\ ${ }^{2}$ Katedra za internu medicinu, Fakultet medicinskih nauka, Univerzitet u Kragujevcu, Srbija \\ ${ }^{3}$ Katedra za mikrobiologiju, Medicinski fakultet Foča, Univerzitet u Istočnom Sarajevu, Bosna i Hercegovina \\ ${ }^{4}$ Katedra za otorinolaringologiju, Fakultet medicinskih nauka, Univerzitet u Kragujevcu, Srbija \\ ${ }^{5}$ Centar za molekularnu medicinu i istraživanje matičnih ćelija, Fakultet medicinskih nauka, Univerzitet u Kragujevcu, Srbija
}

\begin{abstract}
Chronic Hepatitis $C$ virus (HCV) infection is defined as persistence of HCV RNA in the blood for more than six months. HCV is a major cause of chronic liver disease and cirrhosis. It's serious public health problem, affects about 71 million people worldwide. $H C V$ doesn't destroy hepatocytes directly. It activates the host's innate and acquired immune system and causes liver injury indirectly. Behind hepatic, $\mathrm{HCV}$ can cause extra-hepatic manifestations. One of them is renal disease which can lead to end-stage renal disease, ESRD. The prevalence of HCV infection in patients on hemodialysis is high, ranging from 5\% to $60 \%$. HCV infection is a significant cause of morbidity and mortality in patients with ESRD on hemodialysis. In this review, we discuss HCV infection and chronic renal disease as comorbidities, their severity and outcome.
\end{abstract}

Keywords: $H C V$, infection, chronic renal disease, comorbidity.

\section{SAŽETAK}

Hronična hepatitis C virusna (HCV) infekcija se definiše kao prisustvo HCV RNA u krvi duže od šest meseci. Glavni je uzrok hronične bolesti jetre i ciroze. Oko 71 milion ljudi širom sveta je inficirno ovim virusom koji predstavlja ozbiljan zdravstveni problem. HCV ne uništava hepatocite direktno. Aktivira urođeni $i$ stečeni imunski sistem domaćina i indirektno oštećuje jetru. Osim oštećenja jetre, HCV izaziva i ekstrahepatične manifestacije. Jedna od njih je bubrežna bolest koja može da progredira do završnog stadijuma bubrežne bolesti (engl. end-stage renal disease, ESRD). Prevalencija HCV-a kod pacijenata na hemodijalizi je velika, kreće se od 5\% do 60\%, a HCV infekcija je značajan uzrok oboljevanja i smrtnosti kod pacijenata sa ESRD na hemodijalizi. U ovom preglednom članku, mi razmatramo HCV infekciju, hroničnu bubrežnu bolest kao komorbiditete, njihovu težinu i ishod.

Ključne reči: $H C V$, infekcija, hronična bubrežna bolest, komorbiditet. 


\section{ETIOLGY, EPIDEMIOLOGY AND IMMUNO-PATHOGENESIS OF HCV INFECTION}

Hepatitis $\mathrm{C}$ virus (HCV) is a positive single-stranded RNA virus with $9.6 \mathrm{~kb}$ in length, belongs to the genus Hepacivirus in the family Flaviviridae (1). HCV genome encodes seven non-structural (NS) proteins (NS1 or P7, NS2, NS3, NS4A, NS4B, NS5A and NS5B) and three structural proteins (Core, E1 and E2) (2). They are the host's target of the innate and adaptive immune response $(2,3)$. Hepatitis $\mathrm{C}$ virus (HCV) transmission occurs on parenteral way (by intravenous drug injection, by parenteral exposure of blood through the use of contaminated or inadequately sterilized instruments and needles used in medical and dental interventions, organ transplantation, hemodialysis), or by other activities that disrupt the integrity of the skin (e.g. tattooing, piercing), sexual way, vertical way (prenatal, perinatal and postnatal) $(4,5,6)$. Number of chronically infected patients with $\mathrm{HCV}$ is about 71 million worldwide (7).

$\mathrm{HCV}$ has a high genomic variability, 7 genotypes and at least 67 subtypes (8). Determination of HCV genotypes and subtypes is important for the definition of epidemiological patterns and effective treatment (8). The most frequently genotypes in world are genotype 1, 2, 3 (8). Genotype 4 is one of the more difficult genotypes to treat (9). Although association between HCV genotype and fibrosis progression appears inconclusive, some studies revealed that infection with genotype 3 has higher risk of severe hepatic steatosis, fibrosis progression and increased oncogenesis $(9,10,11,12,13)$.

Hepatocytes are the main place of $\mathrm{HCV}$ replication. Cellmediated immune reaction against infected liver cells causes the most injury in the liver (14). Host's first-line antiviral defense mechanism is innate immunity, characterized by production of interferons (IFNs) and pro-inflammatory cytokines (1). Interferon type I in infected cells induces accumulation of double-stranded RNA-dependent protein kinase (PKR), expression of genes which induce the apoptosis of infected hepatocytes and inhibition of viral replication $(3,15)$. Parenchymal cells (hepatocytes), non-parenchymal liver cells (Kupffer cells (KCs), hepatic stellate cells (HSCs)) and immune cells (dendritic cells and NK cells, mast cells, macrophages) recruited to the liver are enrolled in anti-viral immune response, so these cells play a key role in the elimination of acute HCV infection within 6 months from onset (1, 16, 17). Retinoic acid-inducible gene-I (RIG-I)-like receptors and Toll-like receptors are the main pattern recognition receptors that recognize $\mathrm{HCV}$ pathogen-associated molecular patterns (3). During HCV infection, TLR3 and RIG-I on infected hepatocytes, TLR7 on Plasmacytoid dendritic cells (pDC) are engaged by HCV RNA to induce the secretion interferons type I and III which further inhibit HCV replication and activate NK cells (3). Activated NK cells produce IFN- $\gamma$ and $\mathrm{TNF} \alpha$, which inhibit $\mathrm{HCV}$ replication and induce DC maturation. Activation and differentiation of $\mathrm{CD}^{+} \mathrm{T}$ cells and $\mathrm{CD}^{+} \mathrm{T}$ cells into Th1 cells and Cytotoxic T cells (CTL) is facilitated by IL-12, produced mainly by matured DCs (3).
These cells secrete IL-12 and IL-15 and activate NK cells (3). CTL and activated NK cells produce perforin and granzyme $\mathrm{B}$ that induce the cytolysis of HCV-infected cells (3). Th1 cells secrete IL-2 which induce the proliferation of CD8 T cells, as well as TNF $\alpha$ which inhibits HCV replication inducing a cytolysis of $\mathrm{HCV}$-infected cells (3). Th1 cells produce IFN- $\gamma$ and induce the differentiation of B cells into plasma cells which produce neutralizing antibodies (3). Targets of neutralizing antibodies are HCV E1 and E2 molecules (18). The effect of humoral anti-viral response is neutralization of viral and cellular factors which promote $\mathrm{HCV}$ entry into host cells. Neutralizing antibodies inhibit the binding of HCV to host cellular receptors $(3,18)$. In more than $80 \%$ of infected patients acute phase progrediates to chronic infection because of limitation of immune responses to eliminate the virus $(2,3,4,19)$. Persistence of Hepatitis $C$ viral infection in the host can be explained with virus ability to evade immune surveillance thanks to viral mutation and inhibition of innate immune cells such as dendritic cell (DC) and natural killer (NK) cells by HCV viral proteins (3). Additionally, virus has ability to alter innate and adaptive immune response, by involvement of Regulatory T cells (Tregs) (3). There are opinions that Tregs have a central role for HCV persistence (20). Tregs suppress activation and differentiation of many immuno-competent cells, block co-stimulation by DCs and induce apoptosis of activated effector T cells (20). Treg subsets produce TGF- $\beta$ and subsequently stimulate fibrosis (20). Some studies showed increased number of regulatory $\mathrm{T}$ cells in peripheral blood and in liver tissue of chronic HCV patients (20). Constant inflammatory response in liver mediated by pro-inflammatory cytokines/ chemokines (IL-6, TGF- $\beta 1$, IL-1 $\beta$, IL-18 and CCL5) released from HCV-infected hepatocytes and liver macrophages, may lead to the activation of quiescent hepatic stellate cells (HSCs) which develop a myofibroblastic phenotype to secrete and deposit the extracellular matrix (ECM) proteins such as collagen type I, resulting in development of fibrosis and cirrhosis. $(21,22)$. HCV induce fibrosis by upregulating miR-192 expression via HCV core protein and enhancing expression of mayor potent profibrogenic cytokine, TGF- $\beta 1(21)$. TGF- $\beta 1$ is a main potent profibrogenic cytokine and plays a key role in pathogenesis of liver fibrosis (21). Activation and proliferation of hepatic myofibroblasts is the main mechanism in liver cirrhosis development (22). Perforin/granzyme pathway, Fas ligand released from inflammatory cells with its receptor Fas on hepatocytes, is other candidate mechanism to enhance liver damage (23).

\section{OUTCOME AND CLINICAL MANIFESTATIONS OF HCV INFECTION}

Acute HCV infection leads to chronic hepatitis and eventually causes fibrosis, cirrhosis (in $20-30 \%$ of cases) and hepatocellular carcinoma (HCC in $1-5 \%$ of cases) (5). Hepatitis $\mathrm{C}$ is resolved spontaneously by involving innate and adaptive immunity in less than $20 \%$ of patients $(4,5,6,17)$. Chronic HCV infection is defined as viral replication which persists for more than six months (24). Patients in this stage are usually asymptomatic, and transaminases are increased or 
in normal range (24). Only $15 \%$ of infected patients have symptoms (17). The most frequent manifestations include unspecific signs like fatigue, fever, myalgia, nausea, arthralgia, abdominal pain, pruritus and anorexia $(17,25)$. Other symptoms include jaundice, bilirubinuria and very rarely light colored stools $(17,25,26,27,28)$. Chronic HCV infection causes hepatic and extrahepatic manifestations $(29,30$, $31,32,33,34,35,36)$. Infected HCV patients can develop extrahepatic manifestations caused by immune abnormalities which result in autoimmunity (26). At least one extrahepatic manifestation occurs in $38 \%$ to $76 \%$ patients with chronic $\mathrm{HCV}$ infection $(26,37)$. Extrahepatic manifestations include mixed cryoglobulinemia-the most frequent $60 \%-75 \%$, chronic kidney disease or end-stage renal disease, membranoproliferative glomerulonephritis type 1, type 2 diabetes, Bcell lymphoma, lichen planus, porphyria cutanea tarda, Sjögren's syndrome, rheumatoid-like arthritis, SLE, depression, autoimmune thyroiditis, idiopathic pulmonary fibrosis, antiphospholipid syndrome, sarcoidosis, sysitemic slerosis, Behcet disease, xerophthalmia; cardiovascular manifestations as carotid atherosclerosis, coronary heart disease; neurological conditions as peripheral neuropathy, cognitive impairment and cerebrovascular accidents; $(26,29,30,31,32$, $33,34,35,36,38)$.

\section{DIAGNOSIS AND THERAPY OF CHRONIC HCV INFECTION}

Diagnostic criteria for $\mathrm{HCV}$ infection is presence of anti HCV antibody and HCV RNA (39). HCV RNA is the first detectable virus marker that appears one to two weeks after exposure (17). The anti-HCV IgG response can be detected seven-eight weeks later, and standard test to detect anti-HCV antibodies in serum and plasma is an immunoassay or enzyme-linked immunosorbent assay (EIA) (17, 40, 41). Quantitative HCV RNA assays are used to confirm the presence of infection, to quantify the amount of HCV RNA, and to guide decisions for antiviral therapy (41). Real-time PCR methods despite standard PCR methods have better sensitivity for HCV level testing (41).

Treatment of chronic $\mathrm{HCV}^{+}$patients is based first of all on genotype, extent of fibrosis or cirrhosis and comorbidities (4). Treatment of HCV infection has been changed for years and it has evolved from using nonspecific antiviral therapy, interferon, to interferon and nucleoside analog, ribavirin (4, 8). Later, is showed that pegylated interferon (peg-IFN) is more effective than non-pegylated one, and combination of PegIFN $\alpha$ and ribavirin had been the standard of care before using DAAs (Direct-acting antiviral agents) (8). Interferon/Ribavirin therapy combination, for 24-48 weeks, eradicated the virus in approximately $50 \%$ of treated patients (42, 43). Each genotype has different response to antiviral therapy (8). HCV genotype with HCV-RNA baseline level is the major predictor of sustained virological response (SVR) to antiviral therapy (8).

$\mathrm{HCV}$ infected patients with genotype 2-and 3 reach sustained virological response (SVR) using pegylated-interferon in combination with ribavirin (pegIFN/RBV) in $80 \%$; genotype 1 and 4 infections leads to an SVR only for about $50 \%$; genotypes 5 and 6 have intermediate response rates, while infected patients with genotype 3 with dual pegIFN/RBV therapy have SVR rates worse than infected patients with genotype $2(8,13,43)$. Since 2011. Direct-acting antivirals (DAAs) are being used for treatment of chronic hepatitis and their targets are viral proteins NS3, NS5A, and NS5B (43, 44). The first-generation NS3/4A protease inhibitors, boceprevir and telaprevir, used in combination with PEG-IFN$\alpha$ and Ribavirin leads to SVRs in approximately $70 \%$ of $\mathrm{HCV}$ genotype 1-infected patients (44). As this triple therapy showed some bad effects and led to the generation of drugresistant $\mathrm{HCV}$, they are no longer recommended (44). The protease inhibitors (simeprevir, paritaprevir, grazoprevir, glecaprevir, and voxilaprevir), the NS5A inhibitors (velpatasvir, pibrentasvir, and daclatasvir), and the NS5B inhibitors (sofosbuvir and MIV-802) present higher barrier to viral resistance, cover more of the viral genotypes, have better pharmacokinetics, have high SVRs and an excellent tolerability profile also in patients with renal impairment $(9,43$, $44,45)$. Success of therapy is increased from the $15 \%$ to $20 \%$ by the IFN $\alpha$ monotherapy (which has a high relapse rate) to over $90 \%$ by the DAA treatments $(43,46,47)$. The goal of treatment in HCV infection is achievement of a SVR (41). SVR is defined as undetectable HCV RNA in peripheral blood 12 weeks after the end of the treatment (41). Limiting factor, first of all in developing countries, for usement of DAA, is high cost (48).

\section{CHRONIC KIDNEY DISEASE (CKD)}

Chronic kidney disease (CKD) is defined as a renal parenchyma damage leading to chronic deterioration of renal function that may progress to end-stage renal disease (ESRD) gradually (49). The term CKD has replaced previously used terms "chronic renal insufficiency" and "chronic renal failure" (49). CKD is characterized by abnormal albumin excretion or decreased kidney function, quantified by glomerular filtration rate (GFR), of less than $60 \mathrm{~mL} / \mathrm{min}$ per $1.73 \mathrm{~m}^{2}$ that persists for more than three months. $(49,50,51)$ Most often used equation for estimating glomerular filtration rate (GFR) from serum creatinine is Cockcroft-Gault equation. $(49,50$, 51) The Kidney Disease Improving Global Outcomes (KDIGO) organization classified the stages of CKD using a "traffic light" staging system based on eGFR(G1-G5) and albuminuria (A1-A3) (52).

Table 1. Chronic kidney disease stages

\begin{tabular}{ll} 
Stage & eGFR value \\
\hline I & $\begin{array}{l}\text { normal or high eGFR } \geq 90 \mathrm{~mL} / \mathrm{min} \text { per } \\
1.73 \mathrm{~m}^{2}\end{array}$ \\
II & $\begin{array}{l}\text { eGFR between } 60 \text { to } 89 \mathrm{~mL} / \mathrm{min} \text { per } 1.73 \\
\mathrm{~m}^{2}\end{array}$ \\
IIIa & $\begin{array}{l}\text { eGFR between } 45 \text { to } 59 \mathrm{~mL} / \mathrm{min} \text { per } 1.73 \\
\mathrm{~m}^{2}\end{array}$ \\
IIIb & $\begin{array}{l}\text { eGFR between } 30 \text { to } 44 \mathrm{~mL} / \mathrm{min} \text { per } 1.73 \\
\mathrm{~m}^{2}\end{array}$ \\
\hline
\end{tabular}




\begin{tabular}{ll} 
Stage & eGFR value \\
\hline IV & $\begin{array}{l}\text { eGFR between } 15 \text { to } 29 \mathrm{~mL} / \mathrm{min} \text { per } 1.73 \\
\mathrm{~m}^{2} \\
\text { eGFR of }<15 \mathrm{~mL} / \text { min per } 1.73 \mathrm{~m}^{2} \text { or end- } \\
\text { stage renal disease }\end{array}$ \\
V & $\begin{array}{l}\text { albuminuria(usually measured by urinary } \\
\text { albumin-to-creatinine ratio) }\end{array}$ \\
$\mathbf{A 1}$ & $<30 \mathrm{mg} / \mathrm{g}$ \\
$\mathbf{A 2}$ & $30-300 \mathrm{mg} / \mathrm{g}$ \\
$\mathbf{A 3}$ & $>300 \mathrm{mg} / \mathrm{g}$ \\
\hline
\end{tabular}

CKD presents a serious public health problem, affecting $8-16 \%$ of the adult population worldwide (53). Risk factors for kidney damage are: diabetes and high blood pressure, high cholesterol, female sex, age $>60$ years, African American ethnicity, obesity, smoking, inflammatory kidney diseases (54). As kidneys in CKD become affected by tubulointerstitial fibrosis and exhibit nephron loss, they aren't able to remove metabolic "waste", including end-products of protein metabolism (49). Impaired renal clearance leads to accumulation of "uremic toxins" and have negative impact on different biological functions, especially on the inflammatory, cardiovascular and fibrogenic systems (49). There are no obvious clinical symptoms in early stage disease but as time goes, some of the manifestations appear: loss of appetite, nausea and vomiting, itching, muscle cramps, anemia, hemathuria, proteinuria, decreased urine output or more frequent urination, especially at night, hypertension, edema (55). As people with CKD can be asymptomatic, diagnostic tests which include the measurement of the creatinine level in the blood and protein in the urine, are the only way to find out for disease (54). Diagnostic critera for CKD are: decreased eGFR $(<90 \mathrm{~mL} / \mathrm{min} / 1.73 \mathrm{~m} 2)$ and one or more marker of kidney demage (albuminuria, urinary albumin to creatinine ratio (ACR) $\geq 30 \mathrm{mg} / \mathrm{g}(3 \mathrm{mg} / \mathrm{mmol})$, structural and histological abnormalities, electrolyte and other abnormalities due to tubular disorders, urine sediment abnormalities (hematuria, red or white blood cell casts, oval fat bodies or fatty casts, granular casts, and renal tubular epithelial cells) present for at least 3 months $(52,54)$. High blood pressure may also point to underlying chronic kidney disease $(52,54)$. As there is no current medicament for CKD, in usement are some which can help control the signs and symptoms, reduce the risk of complications, and slow the progression of the disease (56). Some of mediacaments which can be used for treatment of $\mathrm{CKD}$, include mineralocorticoid-receptor antagonists, ACE inhibitors, sodium/glucose cotransporter 2 inhibitors, anti-inflammatory drugs, drugs that mitigate oxidative injury, and at the end hemodialysis which is reserved for those patients with ESRD (56).Chronic kidney disease is associated with some complications, usually when GFR declines below $60 \mathrm{~mL} / \mathrm{min} / 1.73 \mathrm{~m} 2$, including increased incidence of cardiovascular disease, hyperlipidemia, anemia and metabolic bone disease, neurogical, infectious disease (50, $53,57)$.

\section{CHRONIC KIDNEY DISEASE AND COMORBIDITIES}

Comorbidities in CKD include first of all hypertension, diabetes, hyperlipidemia, cerebrovascular disease, malignancy, liver disease, anemia, ischemic heart disease, gout, connective tissue disease, congestive heart failure, thyroid disorder, tuberculosis (58). Hypertension as one of main comorbidity in CKD patients, increased death by nearly $20 \%$ for every $10 \mathrm{mmHg}$ higher diastolic blood pressure, and 45\% of the patients with ESRD already have advanced manifestations of cardiovascular disease (59). Diabetes Mellitus is present in about $30-40 \%$ of all patients with ESRD (59). Patients with three or more comorbidities, male sex, lower baseline eGFR were associated with faster CKD progression, increased risk for dialyzing $(58,59)$.

\section{CHRONIC KIDNEY DISEASE AND HCV}

As we know, chronic HCV infection, which can lead to cirrhosis and hepatocellular carcinoma, also results in numerous other complications, including impairment of renal function (14). Chronic kidney disease (CKD) is one of the most common extrahepatic manifestations in patients with chronic $\mathrm{HCV}$ (38). In some study it was showed that HCV-infected patients had a $27 \%$ increased risk of CKD, compared with non-HCV patients $(14,38)$. There are some suggested pathogenic mechanisms of HCV-mediated renal syndromes: direct viral invasion of the renal parenchyma; deposition of immune complex in glomeruls, renal complications of HCV infection; and nephrotoxicity of antiviral drugs (14). We can say that $\mathrm{HCV}$ infection is associated with renal disease, as both the cause and the consequence $(14,35)$. On the other side, patients with end-stage renal disease (ESRD) treated with hemodialysis are at particular risk of acquiring $\mathrm{HCV}$ because of permanent vascular access, frequent exposure to possibly contaminated equipment $(60,61)$. The prevalence of $\mathrm{HCV}$ in patients on hemodialysis is high, ranging from $5 \%$ to $60 \%$ (62). The most represented genotypes in dialysis patients are 1a, 1b, 3 (49). In hemodialysis centers, the most frequent contamination is inappropriate handling of equipment by hemodialysis (HD) center staff, inappropriate disinfection and cleaning of surfaces, inappropriate parenteral administration of drugs (63). In one study revealed that patients with $\mathrm{HCV}$ and ESRD have less progression of liver injury, decreased level of AST, ALT and LDH, increased systemic level of IL6 and Gal-3, and no significant differences in the concentrations of IL- $1 \beta$, IL-4, and IL-23 and anti-HCV antibodies in comparison with $\mathrm{HCV}+$ patients without ESRD (61). It was noticed that increased systemic level of IL-6 and Gal-3 in ESRD $\mathrm{HCV}^{+}$patients have hepatoprotective role (61). Gal-3 has hepatoprotective activity in ESRD HCV+ patients on two ways: inhibits local inflammation and consequent destruction of hepatocytes, and inhibits apoptosis (protects mitochondrial membrane integrity, inhibits caspase activation, inhibits releasing of cytochrome C) (61). IL-6 stimulates proliferation of hepatocytes and nonparenchymal cells in the liver, during infection IL-6 induces acute phase protein production in the liver and helps expression of many protective genes in the 
hepatocytes stimulating hepatocyte proliferation and their survival (51). Gal-3 and IL-6 protect the liver from virus destruction, subsequently decreasing systemic level of AST and ALT and also stimulates liver regeneration (61). In one study was tested IL-33/sST2 pathway in ESRD HCV+ patients and $\mathrm{HCV}+$ patients without ESRD (64). They found positive correlation between serum level of SST2 and urea and creatinine, and no effect of viral activity on systemic value of sST2 (64). For the first time it was noticed increased level of sST2, significantly increased sST2/IL-1, sST2/IL-4 and sST2/IL-23 ratio in ESRD $\mathrm{HCV}+$ patients in comparison with $\mathrm{HCV}+$ patients (64). Soluble form of ST2 is a decoy receptor for IL33, which blocks IL-33/ST2 signaling and inhibit inflammation, so ST2 can be considered as an immunosuppresive molecule targeting innate and aquired anti HCV immune response. (64). This implicate less liver damage and its protective role of sST2 in ESRD HCV+ patients (64).

Patients on hemodialysis should be tested on HCV every 6 months and repeat ALT monthly which is increased in those patients (65). Very careful treatment of HCV is necessary for patients with ESRD (66). It was shown that usement of ribavirin for $\mathrm{HCV}$ infection in ESRD patients can cause hemolytic anemia (66).

Glecaprevir/pibrentasvir, or paritaprevir/ritonavir/ombitasvir/dasabuvir combination or grazoprevir plus elbasvir regimen can be given to patients with GFR $<60$ and $>30$ $\mathrm{ml} / \mathrm{min} / 1.73 \mathrm{~m}^{2}$. Sofosbuvir also can be used but only if there are no other options (66). When patients have a GFR of $<30$ and $>15 \mathrm{ml} / \mathrm{min} / 1.73 \mathrm{~m}^{2}$, only paritaprevir/ritonavir/ombitasvir/dasabuvir or grazoprevir plus elbasvir regimen can be used (66). The active metabolite of sofosbuvir is eliminated by the kidneys and its use is restricted to patients who have eGFR of $\geq 30 \mathrm{ml} / \mathrm{min}$ per $1.73 \mathrm{~m}^{2}(66)$. For patients with ESRD (GFR $<15 \mathrm{ml} / \mathrm{min} / 1.73 \mathrm{~m}^{2}$ or dialysis patients), glecaprevir/pibrentasvir or grazoprevir plus elbasvir combination may be given (66). Some DAA regimens have been demonstrated to have high safety and efficacy for patients with advanced CKD and ESRD, including glecaprevir/pibrentasvir, which effectively treatsall genotypes of $\mathrm{HCV}$; elbasvir/ grazoprevir for HCV genotypes 1 and 4; ombitsavir/dasabuvir/paritaprevir/ritonavir for genotype 1(67).

\section{CONCLUSION}

$\mathrm{HCV}$ infection and renal disease are strongly linked. On the one side $\mathrm{HCV}$ infection increases the risk of CKD and its progression to ESRD, at the other side patients who are on hemodialysis are in big risk to get HCV infection. Recent studies revealed that ESRD patients have increased systemic level of some cytokines and immunomodulatory mediators that play hepatoprotective role which correlate with less progression of liver injury in comparison with $\mathrm{HCV}+$ patients without ESRD. Several direct-acting antivirals (DAAs) have been approved for clinical use, including NS3/4A, NS5A and NS5B inhibitors The combination of these DAAs has become the standard treatment for patients with HCV infection, which greatly improves sustained virologic response (SVR) rates to over $90 \%$, and for patients with $\mathrm{HCV}$ infection $\mathrm{CKD}$ / ESRD.

\section{ACKNOWLEDGEMENTS}

This work was supported by grants from the Serbian Ministry of Science and Technological Development (175069), bilateral project with PR China (06/2018) and from the Faculty of medical sciences Kragujevac (projects JP 02/20, JP 15/19, JP 11/18), Serbia.

\section{CONFLICT OF INTEREST}

The authors declare no financial or commercial conflict of interest.

\section{REFERENCES}

1. Chan ST, Ou JJ. Hepatitis C Virus-Induced Autophagy and Host Innate Immune Response. Viruses. 2017;9(8):224.

2. Li H, Huang MH, Jiang JD, Peng ZG. Hepatitis C: From inflammatory pathogenesis to anti-inflammatory/hepatoprotective therapy. World J Gastroenterol. 2018;24(47):5297-5311.

3. Chigbu DI, Loonawat R, Sehgal M, Patel D, Jain P. Hepatitis $\mathrm{C}$ Virus Infection: Host ${ }^{-}$Virus Interaction and Mechanisms of Viral Persistence. Cells. 2019;8(4):376.

4. Wilkins T, Akhtar M, Gititu E, Jalluri C, Ramirez J. Diagnosis and Management of Hepatitis C. Am Fam Physician. 2015;91(12):835-842.

5. Chen SL, Morgan TR. The natural history of hepatitis $\mathrm{C}$ virus (HCV) infection. Int J Med Sci. 2006;3(2):47-52.

6. Manns MP, Buti M, Gane E, et al. Hepatitis C virus infection. Nat Rev Dis Primers. 2017;3:17006.

7. Coppola N, Alessio L, Onorato L, et al. Epidemiology and management of hepatitis $\mathrm{C}$ virus infections in immigrant populations. Infect Dis Poverty. 2019;8(1):17.

8. Ansaldi F, Orsi A, Sticchi L, Bruzzone B, Icardi G. Hepatitis $\mathrm{C}$ virus in the new era: perspectives in epidemiology, prevention, diagnostics and predictors of response to therapy. World J Gastroenterol. 2014;20(29):96339652.

9. Di Biagio A, Taramasso L, Cenderello G. Treatment of hepatitis $\mathrm{C}$ virus genotype 4 in the DAA era. Virol $\mathrm{J}$. 2018;15(1):180.

10. Bostan N, Mahmood T. An overview about hepatitis C: a devastating virus. Crit Rev Microbiol. 2010;36(2):91133.

11. Negro F. Steatosis and insulin resistance in response to treatment of chronic hepatitis C. J Viral Hepat. 2012;19 Suppl 1:42-47.

12. van der Meer AJ, Veldt BJ, Feld JJ, et al. Association between sustained virological response and all-cause mortality among patients with chronic hepatitis $\mathrm{C}$ and advanced hepatic fibrosis. JAMA. 2012;308(24):25842593. 
13. Goossens N, Negro F. Is genotype 3 of the hepatitis $\mathrm{C}$ virus the new villain?. Hepatology. 2014;59(6):24032412.

14. Kuna L, Jakab J, Smolic R, Wu GY, Smolic M. HCV Extrahepatic Manifestations. J Clin Transl Hepatol. 2019;7(2):172-182.

15. Bigger CB, Brasky KM, Lanford RE. DNA microarray analysis of chimpanzee liver during acute resolving hepatitis C virus infection. J Virol. 2001;75(15):7059-7066.

16. Heim MH, Thimme R. Innate and adaptive immune responses in HCV infections. J Hepatol. 2014;61(1 Suppl):S14-S25.

17. Westbrook RH, Dusheiko G. Natural history of hepatitis C. J Hepatol. 2014;61(1 Suppl):S58-S68.

18. Kinchen VJ, Bailey JR. Defining Breadth of Hepatitis C Virus Neutralization. Front Immunol. 2018;9:1703.

19. Chigbu DI, Loonawat R, Sehgal M, Patel D, Jain P. Hepatitis C Virus Infection: Host ${ }^{-}$Virus Interaction and Mechanisms of Viral Persistence. Cells. 2019;8(4):376.

20. Baskic D, Vukovic V, Popovic S, et al. Correction: Chronic Hepatitis C: Conspectus of immunological events in the course of fibrosis evolution. PLoS One. 2019;14(8):e0221142.

21. Khatun M, Ray RB. Mechanisms Underlying Hepatitis C Virus-Associated Hepatic Fibrosis. Cells. 2019;8(10):1249.

22. Liu X, Xu J, Brenner DA, Kisseleva T. Reversibility of Liver Fibrosis and Inactivation of Fibrogenic Myofibroblasts. Curr Pathobiol Rep. 2013;1(3):209-214.

23. Spengler U, Nattermann J. Immunopathogenesis in hepatitis C virus cirrhosis. Clin Sci (Lond). 2007;112(3):141-155.

24. Scott JD, Gretch DR. Molecular diagnostics of hepatitis C virus infection: a systematic review. JAMA. 2007;297(7):724-732.

25. Czepiel J, Biesiada G, Mach T. Viral hepatitis C. Pol Arch Med Wewn. 2008;118(12):734-740.

26. Morozov VA, Lagaye $S$. Hepatitis $C$ virus: Morphogenesis, infection and therapy. World $\mathrm{J}$ Hepatol. 2018;10(2):186-212.

27. Dias C, Pipa S, Mota M. Acute hepatitis C from heterosexual transmission. IDCases. 2018;14:e00448.

28. Blackard JT, Shata MT, Shire NJ, Sherman KE. Acute hepatitis $\mathrm{C}$ virus infection: a chronic problem [published correction appears in Hepatology. 2008 Feb;47(2):769]. Hepatology. 2008;47(1):321-331.

29. Younossi Z, Park H, Henry L, Adeyemi A, Stepanova M. Extrahepatic Manifestations of Hepatitis C: A Metaanalysis of Prevalence, Quality of Life, and Economic Burden. Gastroenterology. 2016;150(7):1599-1608.

30. Sayiner M, Golabi P, Farhat F, Younossi ZM. Dermatologic Manifestations of Chronic Hepatitis C Infection. Clin Liver Dis. 2017;21(3):555-564.

31. Cacoub P, Comarmond C, Desbois AC, Saadoun D. Rheumatologic Manifestations of Hepatitis C Virus Infection. Clin Liver Dis. 2017;21(3):455-464.

32. Goossens N, Negro F. Cardiovascular Manifestations of Hepatitis C Virus. Clin Liver Dis. 2017;21(3):465-473.
33. Mapoure NY, Budzi MN, Eloumou SAFB, Malongue A, Okalla C, Luma HN. Neurological manifestations in chronic hepatitis $\mathrm{C}$ patients receiving care in a reference hospital in sub-Saharan Africa: A cross-sectional study. PLoS One. 2018;13(3):e0192406.

34. Couronné L, Bachy E, Roulland S, et al. From hepatitis $\mathrm{C}$ virus infection to B-cell lymphoma. Ann Oncol. 2018;29(1):92-100.

35. Flores-Chávez A, Carrion JA, Forns X, Ramos-Casals M. Extrahepatic manifestations associated with Chronic Hepatitis C Virus Infection. Rev Esp Sanid Penit. 2017;19(3):87-97.

36. Tang L, Marcell L, Kottilil S. Systemic manifestations of hepatitis $\mathrm{C}$ infection. Infect Agent Cancer. 2016;11:29.

37. Ozkok A, Yildiz A. Hepatitis C virus associated glomerulopathies. World J Gastroenterol. 2014;20(24):75447554.

38. Park H, Chen C, Wang W, Henry L, Cook RL, Nelson DR. Chronic hepatitis $\mathrm{C}$ virus (HCV) increases the risk of chronic kidney disease (CKD) while effective HCV treatment decreases the incidence of CKD. Hepatology. 2018;67(2):492-504.

39. Guss D, Sherigar J, Rosen P, Mohanty SR. Diagnosis and Management of Hepatitis C Infection in Primary Care Settings. J Gen Intern Med. 2018;33(4):551-557.

40. Maasoumy B, Wedemeyer H. Natural history of acute and chronic hepatitis C. Best Pract Res Clin Gastroenterol. 2012;26(4):401-412.

41. Karnsakul W, Schwarz KB. Hepatitis B and C. Pediatr Clin North Am. 2017;64(3):641-658.

42. Zeuzem S, Berg T, Moeller B, et al. Expert opinion on the treatment of patients with chronic hepatitis C. J Viral Hepat. 2009;16(2):75-90.

43. González-Grande R, Jiménez-Pérez M, González Arjona C, Mostazo Torres J. New approaches in the treatment of hepatitis C. World J Gastroenterol. 2016;22(4):14211432.

44. Tsukiyama-Kohara K, Kohara M. Hepatitis C Virus: Viral Quasispecies and Genotypes. Int $\mathrm{J}$ Mol Sci. 2017;19(1):23.

45. Simonović Babić J, Bojović K, Fabri M, Cvejić T, Svorcan P, Noţić D, Jovanović M, Škrbić R, Stojiljković MP, Mijailović Ț. A real-life data on the efficacy and safety of ombitasvir/paritaprevir/ritonavir + dasabuvir + ribavirin in patients with genotype 1 chronic hepatitis $C$ virus infection in Serbia. Vojnosanit Pregl. 2019; 76(5): 531536.

46. Kim S, Han KH, Ahn SH. Hepatitis C Virus and Antiviral Drug Resistance. Gut Liver. 2016;10(6):890-895.

47. Heim MH. 25 years of interferon-based treatment of chronic hepatitis C: an epoch coming to an end. Nat Rev Immunol. 2013;13(7):535-542.

48. Bojovic K, Simonovic-Babic J, Mijailovic Z, et al. Micro-elimination of $\mathrm{HCV}$ as a possible therapeutic strategy: our experience and a review of literature. J Infect Dev Ctries. 2020;14(2):117-124. 
49. Akchurin OM. Chronic Kidney Disease and Dietary Measures to Improve Outcomes. Pediatr Clin North Am. 2019;66(1):247-267.

50. Thomas R, Kanso A, Sedor JR. Chronic kidney disease and its complications. Prim Care. 2008;35(2):329-vii.

51. Cobo G, Lindholm B, Stenvinkel P. Chronic inflammation in end-stage renal disease and dialysis. Nephrol Dial Transplant. 2018;33(suppl_3):iii35-iii40.

52. Fraser SD, Blakeman T. Chronic kidney disease: identification and management in primary care. Pragmat Obs Res. 2016;7:21-32.

53. Ishigami J, Matsushita K. Clinical epidemiology of infectious disease among patients with chronic kidney disease [published correction appears in Clin Exp Nephrol. 2019 Mar 2;:]. Clin Exp Nephrol. 2019;23(4):437-447.

54. Razmaria AA. Chronic Kidney Disease. JAMA. 2016;315(20):2248.

55. Webster AC, Nagler EV, Morton RL, Masson P. Chronic Kidney Disease. Lancet. 2017;389(10075):1238-1252.

56. Breyer MD, Susztak K. Developing Treatments for Chronic Kidney Disease in the 21st Century. Semin Nephrol. 2016;36(6):436-447.

57. Petrović D, Miloradović V, Poskurica M, Stojimirović B. Srp Arh Celok Lek. 2011;139(3-4):248-255.

58. Lee WC, Lee YT, Li LC, et al. The Number of Comorbidities Predicts Renal Outcomes in Patients with Stage 3-5 Chronic Kidney Disease. J Clin Med. 2018;7(12):493.

59. Reichel H, Zee J, Tu C, et al. Chronic kidney disease progression and mortality risk profiles in Germany: results from the Chronic Kidney Disease Outcomes and
Practice Patterns Study. Nephrol Dial Transplant. 2020;35(5):803-810.

60. Wigneswaran J, Van Wyck D, Pegues D, Gholam P, Nissenson AR. Hepatitis $C$ virus infection in patients with end-stage renal disease. Hemodial Int. 2018;22(3):297307.

61. Lukic R, Gajovic N, Jovanovic I, Jurisevic M, Mijailovic Z, Maric V, Popovska Jovicic B, Arsenijevic N. Potential Hepatoprotective Role of Galectin-3 during HCV Infection in End-Stage Renal Disease Patients. Disease Markers olume 2017; 2017:Article ID 6275987

62. Azmi AN, Tan SS, Mohamed R. Hepatitis C and kidney disease: An overview and approach to management. World J Hepatol. 2015;7(1):78-92.

63. Caragea DC, Mihailovici AR, Streba CT, et al. Hepatitis C Infection in Hemodialysis Patients. Curr Health Sci J. 2018;44(2):107-112.

64. Lukic R, Cupic M, Gajovic N, et al. Increased systemic sST2 in patients with end stage renal disease contributes to milder liver damage during $\mathrm{HCV}$ infection. J Infect Dev Ctries. 2020;14(5):519-526.

65. Nguyen DB, Bixler D, Patel PR. Transmission of hepatitis $\mathrm{C}$ virus in the dialysis setting and strategies for its prevention. Semin Dial. 2019;32(2):127-134.

66. Cacoub P, Desbois AC, Isnard-Bagnis C, Rocatello D, Ferri C. Hepatitis $\mathrm{C}$ virus infection and chronic kidney disease: Time for reappraisal. J Hepatol. 2016;65(1 Suppl):S82-S94.

67. Henson JB, Sise ME. The association of hepatitis C infection with the onset of CKD and progression into ESRD. Semin Dial. 2019;32(2):108-118. 